\title{
Rare cutaneous manifestation of Trichosporon asahii
}

\author{
Jack Schnur, Colton Hawco, Ilya Fonarov, Damian Casadesus
}

Internal Medicine, Jackson Memorial Hospital, Miami, Florida, USA

\section{Correspondence to} Dr Damian Casadesus; dcasadesus@hotmail.com

Accepted 6 June 2021

\section{Check for updates}

(C) BMJ Publishing Group Limited 2021. No commercial re-use. See rights and permissions. Published by BMJ.

To cite: Schnur J, Hawco C, Fonarov l, et al. BMJ Case Rep 2021;14:e243659. doi:10.1136/bcr-2021243659

\section{DESCRIPTION}

An 85-year-old woman with a history of coronary artery disease, heart failure with preserved ejection fraction, hypertension, hyperlipidaemia, diabetes mellitus, chronic obstructive pulmonary disease on home oxygen, pulmonary embolism, gastrointestinal bleeding secondary to erosive gastritis, hypothyroidism and chronic kidney disease presented to the emergency room with acute urinary retention. She was admitted to our institution a month prior with respiratory distress secondary to a pulmonary embolism complicated with cardiac arrest. She was discharged home after a short length of stay. She had a surgical history of a hemicolectomy because of colon cancer 26 years ago.

Early during the hospitalisation, she had a gastrointestinal bleed necessitating transfusion of two units of packed red blood cells. She subsequently developed respiratory failure requiring intubation. Henceforth the patient was managed with respiratory support provided via mechanical ventilation in the intermediate care unit. The patient's condition improved, and 3 days later, she was successfully extubated. Her laboratory studies revealed a white cell count of $6.1 \times 10^{9} / \mathrm{L}$, haemoglobin $83 \mathrm{~g} / \mathrm{L}$ and platelets $192 \times 10^{9} / \mathrm{L}$. In our unit, the cardiopulmonary examination was normal. Skin examination showed an ulcer on the dorsum of the right hand with thickened borders, clean pink tissue at the base with surrounding oedema but without any discharge (figure 1). A detailed history was obtained from the patient regarding the ulcerations on the hand. She stated that the ulcer started as a necrotic wound at the insertion site of a peripheral line a few days after the previous admission.

A skin biopsy was obtained for cytology and culture. In the tissue obtained for culture, Trichosporon asahii was identified by Biomerieux Maldie, a mass spectrometry microbial identification system,

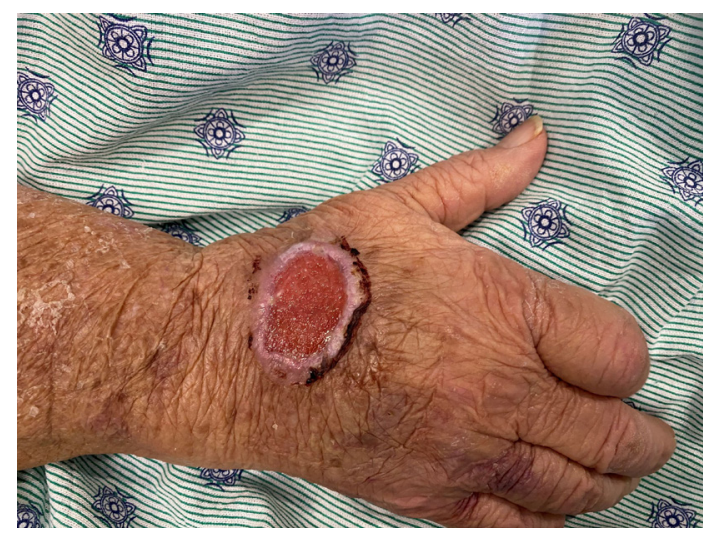

Figure 1 Right hand ulcer with thick defined borders and pink tissue in the base.

\section{Learning points}

- Trichosporon asahii can be associated with skin ulceration in patient without neutropaenia.

- Physicians should consider trichosporonosis as a new emerging cause of non-candida infection.

and the patient started treatment with voriconazole $400 \mathrm{mg}$ orally two times per day. The patient recovered, and 3 days later, she was discharged home to complete a 30-day course of oral antifungal treatment. The patient was readmitted 45 days later due to weakness. Her haemoglobin was $67 \mathrm{~g} / \mathrm{L}$. She received one unit of packed red blood cells and was discharged 24 hours later. During this last admission, the skin ulcer was completed healed.

Trichosporon species, especially T. asabii (formerly known as Trichosporon beigelii and Trichosporon cutaneum), is an emerging and common cause of non-Candida fungaemia. Disseminated trichosporonosis typically starts as an acute febrile illness that progresses to multiorgan failure. In two large studies regarding Trichosporon species, invasive infections were associated with antibiotic therapy, central line use, neutropaenia, high doses of steroids, haematological malignancies and intensive care admissions. ${ }^{1-4}$ The crude mortality rate is more than $50 \%$ of the patients. ${ }^{2}$

Trichosporon species have been misdiagnosed as contaminants because they are part of the skin microbiota. T. asabii is considered the leading cause of disseminated infections. Superficial infections due to T. asahii are sporadic and rare, occurring primarily in immunocompetent patients. ${ }^{56}$ White piedra, a superficial infection of hair shafts, is the most common superficial infection, which mainly occurs in tropical regions. Other cutaneous manifestations have been previously described in very few patients. In five patients, it included erythematous papules more frequently in the trunk and extremities followed by bullae formation. ${ }^{7-9}$ In another patient, a cellulitis with progression into the subcutaneous tissues resulted in a fatal outcome. ${ }^{6}$ In our patient, it initially manifested as central necrosis. At the time of the second admission, it appeared as an ulcer at the site of a prior peripheral line insertion.

Contributors JS, CH and DC participated in the clinical management of the patient. JS, CH and DC obtained and edited the picture. $\mathrm{CH}$, IF and DC have been involved in the drafting and discussion of the manuscript. JS, CH, IF and DC reviewed and approved the final version.

Funding The authors have not declared a specific grant for this research from any funding agency in the public, commercial or not-for-profit sectors.

Competing interests None declared. 
Images in...

Patient consent for publication Obtained.

Provenance and peer review Not commissioned; externally peer reviewed.

\section{REFERENCES}

1 Ruan S-Y, Chien J-Y, Hsueh P-R. Invasive trichosporonosis caused by Trichosporon asahii and other unusual Trichosporon species at a medical center in Taiwan. Clin Infect Dis 2009:49:e11-17.

2 Girmenia C, Pagano L, Martino B, et al. Invasive infections caused by Trichosporon species and Geotrichum capitatum in patients with hematological malignancies: a retrospective multicenter study from Italy and review of the literature. J Clin Microbiol 2005:43:1818-28.

3 Kontoyiannis DP, Torres HA, Chagua M, et al. Trichosporonosis in a tertiary care cancer center: risk factors, changing spectrum and determinants of outcome. Scand I Infect Dis 2004:36:564-9.
4 Ebright JR, Fairfax MR, Vazquez JA. Trichosporon asahii, a non-Candida yeast that caused fatal septic shock in a patient without cancer or neutropenia. Clin Infect Dis 2001;33:e28-30.

5 Ageitos JM, Vallejo JA, Veiga-Crespo P, et al. Oily yeasts as oleaginous cell factories. Appl Microbiol Biotechnol 2011;90:1219-27.

6 Baka S, Tsouma I, Kouskouni E. Fatal lower limb infection by Trichosporon asahii in an immunocompetent patient. Acta Dermatovenerol Croat 2013;21:241-4.

7 Nahass GT, Rosenberg SP, Leonardi CL, et al. Disseminated infection with Trichosporon beigelii. Report of a case and review of the cutaneous and histologic manifestations. Arch Dermatol 1993:129:1020-3.

8 Hsiao GH, Chang CC, Chen JC, et al. Trichosporon beigelii fungemia with cutaneous dissemination. A case report and literature review. Acta Derm Venereol 1994;74:481.

9 Piérard GE, Read D, Piérard-Franchimont C, et al. Cutaneous manifestations in systemic trichosporonosis. Clin Exp Dermatol 1992;17:79-82.

Copyright 2021 BMJ Publishing Group. All rights reserved. For permission to reuse any of this content visit

https://www.bmj.com/company/products-services/rights-and-licensing/permissions/

BMJ Case Report Fellows may re-use this article for personal use and teaching without any further permission.

Become a Fellow of BMJ Case Reports today and you can:

- Submit as many cases as you like

- Enjoy fast sympathetic peer review and rapid publication of accepted articles

- Access all the published articles

Re-use any of the published material for personal use and teaching without further permission

\section{Customer Service}

If you have any further queries about your subscription, please contact our customer services team on +44 (0) 2071111105 or via email at support@bmj.com.

Visit casereports.bmj.com for more articles like this and to become a Fellow 